\title{
The Effect of European Convention and the European Court of Human Rights within Constitutional Order of Kosovo and their Relationship
}

\author{
Dr. Arbëresha Raça Shala \\ Public Prosecutor of the Republic of Kosovo and Lecturer at the University of Prishtina -Kosovo \\ Musa I. Bajraktari
}

LLM, Riga Graduate School of Law; musabajraktari27@gmail.com

Doi:10.5901/mjss.2015.v6n6p41

\begin{abstract}
This paper centers its discussion on human rights issues addressed by the European Convention of Human Rights (ECHR) and its court of Human Rights (ECtHR). The focus is on the relationship between the European Convention/European Court of Human Rights and the Constitutional Court of Kosovo. The parameters measuring this relationship mainly will be tested against the effects of the judgments of the ECtHR and the decisions of the Constitutional Court of Kosovo within the legal system of Kosovo. The paper sheds light on Kosovo's constitutional order system with regards to basic human rights as enshrined in ECHR. As such, in an attempt to emphasize the effect and relationship between the ECHR/ECtHR, are also outlined the challenges of the Kosovo Constitutional justice in its work as the defender of basic human rights and freedoms. Ultimately, it is pointed out that the legal system of Kosovo is decisive to adhering to the principles proclaimed in "Bill of Rights", ECHR, and the jurisprudence of ECtHR.
\end{abstract}

Keywords: ECHR, ECtHR, Kosovo Constitutional Court, and Kosovo's Constitutional order.

\section{Introduction}

In European context, the human rights protection takes place through three main dimensions. The first dimension addresses the issues of human rights through the channels of the Organization of Security and Co-operation in European (OSCE) established in Helsinki in 1975. As of March 2013, the OSCE consists of 57 joining States from Europe, Central Asia and North America (OSCE, 2013). Unlike other dimensions, the safeguard of human rights at OSCE does not take place through binding laws, as it is the case with the European Convention of Human Rights (hereinafter ECHR), rather it takes place by linking security issues concerned, arms control, and the liberalization of trade relations with human rights by way of being leveraged as an incentive to influence the states' behavior for better protection of human rights internally (Bente, 2011, pp. 102-104). It follows the adaption of political commitments in an attempt to address the issues of human rights.

The second dimension to safeguarding human rights in Europe has been established with coming into existence of the European Union, originally with 6 members, while currently having 28 members with headquarter in Brussels. Notably, in the context of the European Union, incorporation of the Charter of Fundamental Rights as legally binding with the introduction of the Lisbon Treaty, not only have changed the design of the Union, but it has given special direction in terms of treatment of human rights.

The third dimension to address human right issues is through the Council of Europe established in 1949 currently having 47 partaking member states, while ECHR and the European Court of Human Rights (hereinafter ECtHR) operates under the auspicious of the Council of Europe. The three dimensions' pathway stipulates that in terms of sources, safeguarding of human rights in European system is a mixed one, but the most notable one, is the system channeled through the Council of Europe. Key features of the relationship between the ECHR/ECtHR in one side, and Kosovo Constitutional Court (hereinafter "KCC") on the other side include rights and freedoms protected under both instruments. Ultimately, this contribution attempts to bestow direct connection of effects between the issues discussed in this piece with relevant situation in Kosovo. 


\title{
2. The Effect of the ECHR within the Domestic Legal Order of Kosovo
}

Since the end of 1999 war, Kosovo witnessed significant development with regard to its political and legal framework. Following the so-called Ahtisaari Plan, in 2008 Kosovo declared its independence. It established basic legal framework commencing with introduction of new Constitution of Kosovo few months after February self-declaration of independence. $\mathrm{KCC}$ made obligatory the application of ECHR in the whole Kosovo legal system. While concerning the impact of ECHR has been prescribed in different ways. Michael Boyle stressed out this impact in his words:

\begin{abstract}
"There seems to be unanimous agreement in Europe today that the European Convention on Human Rights (ECHR) is one of the major developments in European legal history and the crowning achievement of the Council of Europe. The emergence of the authority of the European Court of Human Rights has been described as one of the most remarkable phenomena in the history of international law, perhaps in the history of all law" (Boyle, 2008).
\end{abstract}

Undeniably, the effects of provisions of the ECHR widely was and continue to be a significant play-actor on national legal systems of the Member parties as well as to the non-member parties choosing to apply it. Meanwhile, the ECHR is a tool of harmonizing human rights in national legal systems as well as a way of transposing human rights in European law common to all member states (CorlaNiean, 2013, p. 1).

Without particularizing, glancing through the literature that address the issues of human rights in Europe, the overall perception could be drawn that ECHR takes a position of superior status over domestic legal orders. Nevertheless, broader view of human rights signifies specific incorporation of the ECHR within domestic legal order, the hierarchy of ECHR and the acknowledgment of the national courts, usually are determined by the constitution of each country. Admittedly, it depends entirely as to what method of application uses particular country with regard to the applicability of international treaty law in a domestic national order, be it monism or dualism approach.

Kosovo is not yet a member of the Council of Europe. Thus, one might question as to how is possible, a state that is not a party to the convention is set to abide by its provisions? This has been regulated first and foremost through ECHR and its Protocols, whereby they have taken place and acquired a superiority position since the Constitution of the Republic of Kosovo came into effect. In so doing, by virtue of Article 22 of the Constitution of Kosovo, the ECHR therefore has direct applicable effects as well as has acquired higher status over provisions of domestic laws. Equally, the purpose of Article 22 of constitution has been confirmed in several cases decided by KCC. Having said that, the position of the ECHR in domestic legal order is clearly highlighted in one of its decided cases:

"The European Convention for the Protection of Human Rights and Fundamental Freedoms and its Protocols...were incorporated into the law of Kosovo at the Constitutional level, it being given priority over provisions of laws and other acts of public institutions. This Court must interpret the Constitution and the Convention in a complementary manner bearing in mind the necessity to protect the fundamental rights and freedoms enumerated in both. Many of the countries of Europe, which emerged from totalitarian rule over the last number of years, have adopted European standards for the protection of human rights. Kosovo has done the same. The constitutional system is one, like others, based on the pillars of democracy, human rights and the rule of law" (Ćemailj Kurtisi, v. The Municipal Assembly of Prizren, 2009).

Similar interpretation was emphasized by a mixed panel of EULEX judges in the criminal case of Arben Krasniqi et al, (2011), when interpreting the Article 156 (2) of the Kosovo Code of Criminal Procedure (KCCP) in the light of ECHR, whereby the effect of this article is ought to be in conjunction with the ECHR provisions and the jurisprudence of ECtHR. Furthermore, the mixed panel of EULEX judges held:

"Art. 22 of the Constitution make the ECHR directly applicable to the Kosovo domestic legal system. Furthermore, Art. 53 of the Kosovo Constitution requires that 'human rights and fundamental freedoms guaranteed by the Constitution are interpreted consistent with the court decisions of the European Court of Human Rights'... Therefore, the Trial Panel must interpret the KCCP Art.156 (2) 'opportunity to challenge' in line with the ECtHR's findings" (Arben Krasniqi et al, 2011).

Respectively it could be argued that not only the Constitutional Court of Kosovo is obliged to comply with ECHR provisions and with ECtHR case law, but also the other courts in Kosovo can utilize the provisions of ECHR in an effort to provide a correct analysis of the ECHR and appropriate construing of provisions of native laws, i.e. Article 156 (2) of KCCP.

Moreover, the Constitution of Kosovo that entered into force on 15 June 2008 is not the only document that determines the position of ECHR in the legal system of Kosovo (Botusharova, 2013, p. 73). There are two other 
documents that in one way or the other encapsulate the ECHR as an integral part of the Kosovo's legal system, namely: the Comprehensive Proposal for the Kosovo Status Settlement of 26 March 2007, proposed the United Nations Special Envoy for Kosovo, also become known as the Ahtisaari Plan (UN, 2013), and the Kosovo Declaration of Independence, declared on 17 February 2008 (Assembly of Kosovo, 2013).

At heart, the relevance of these two documents represents the act of granting rights from the historical as well as normative rules of an international perspective in agreement with ECHR.

Be as it may, the application of ECHR for the first time in Kosovo was presented through the Constitutional Framework for Provisional Self-Government in Kosovo via the United Nations Mission in Kosovo (UNMIK) in 2001, specifically by virtue of the Chapter 3, (3), (2) of the same document. Only then the so-called Ahtisaari plan amongst others calls upon institutions in Kosovo to take all necessary steps in securing all rights enshrined in the ECHR (UN, 2007, article 2.1). Meanwhile, Article (2. 4) together with the Annex I of the Ahtisaari's plan set the scene for the Constitution of Kosovo as to what international instruments should be incorporated into the future Constitution. At present, they are listed in Article 22.

In turn, the Declaration of Independence of Kosovo through its paragraphs made legally binding the Ahtisaari's plane. Specifically the undertaken commitments may be noted in paragraphs four and five when promoting and protecting fundamental rights as defined by ECHR in line with Ahtisaari's Plan. Also, the last paragraph of the Declaration of Independence, conveys the same message, "Kosovo shall be legally bound to comply with the provisions contained in the Declaration, including, especially, the obligations for it under the Ahtisaari Plan" (Assembly of Kosovo, 2013, para 12).

In this context, it could be argued that political movements were the driving force for the subsequent guidelines of the 2008 Constitution of Kosovo. That leaves no choice but to comply and incorporate the guidelines of Ahtisaari Plan and the commitments of the Declaration of Independence in the newest Constitution in Europe. At the present, the Ahtisaari Plan is embraced in Article 143 of the constitution. Indeed, this article puzzles the issue of the hierarchy between the Plan and the text of the Constitution.

Up to this point, a simple conclusion indicates that ECHR has practical relevance in the legal system of Kosovo, and a great amount of trust has been conversed between the Kosovo legal system and the ECHR. Yet, when we discuss the impact of the ECHR in Kosovo's legal system, the issue of applicability of the ECHR in Kosovo's system deserves some more attention. The reception mode of international documents in Kosovo could be viewed from two different prisms. The first one is transposed through Article 19 of the Constitution of Kosovo, but that only for ratified international agreements for matters enumerated in Article 18 (1) (1-4). Upon the conclusion of the ratification process, they will become legally binding and have superiority over the laws of the Republic of Kosovo (Constitution of Republic of Kosovo, article 19.2). On the other hand, the instruments enumerated in Article 22 imply the same position with a single difference of being directly applicable without ratification. In short, for the issues stated in Article 18 the ratification process channeled through parliament of Kosovo should take place, but it's not the case for instruments listed in Article 22 (Istrefi et al., 2013, pp. 267-282).

Hence, the constitutional design of Kosovo for many authors discussing on this issue implies to adopting a monist approach in establishing the relationship between international law and national law (Morina, Korenica and Doli, 2011). But how this approach is being transformed into constitutional law of Kosovo with respect to human rights as defined in ECHR? From the constitutional point of view, the most essential provision in this regard is undoubtedly Article 22, which is in compliance with monist approach. Likewise, the jurisprudence of the KCC applies the monist approach without giving any explicit explanation, rather giving direct effect of it's application in Kosovo's legal system (Ćemailj Kurtisi, v. The Municipal Assembly of Prizren, 2010, para 40). While, by cross-referring to Article 53 Constitution of Kosovo and giving its effect to the Strasbourg case law only strengthen the argument that monist theory is happily accommodated in the legal system of Kosovo. The effect of the Article 53 will be dealt in greater detail in the following section.

\section{Applicability of ECHR to Non-member Parties to the Convention}

The Republic of Montenegro is the $47^{\text {th }}$ country affiliated to the Council of Europe's membership, while the next country in line at some point will be Kosovo. Whereas, it is well-established fact, the ECHR is legally binding only upon the states member to it. At this point, another argument that deserves attention is to further quest for other arguments with regard to the applicability of the ECHR to non-signing parties such as Kosovo. ECHR as a regional instrument creates civil and political rights, which in turn through its preamble draws from the Universal Declaration of Human Rights. Remarkably the preamble states:

"Being resolved, as the governments of European countries which are like-minded and have a common heritage of 
political traditions, ideals, freedom and the rule of law, to take the first steps for the collective enforcement of certain of the rights stated in the Universal Declaration" (ECHR, preamble).

Translating the above passage into a far-reaching perspective some argue that, "there is no such thing as a 'European human right,' but universal rights. There is rather a 'European' system of protection of these rights" (Boyel, 2009, p. 168). The above posed concept in Kosovo's context, indicate nothing but the ECHR provisions as such are applicable in the legal order of Kosovo. In other words, the Convention is a document, for the protection of all people irrespective of nationality or citizenship based on universality of human rights. Beyond that, the interplay between human rights enshrined in the Constitution of Kosovo in one side, and the universality of human rights referred by ECHR through its provisions provides a solid foundation of the applicability of ECHR in Kosovo.

The second argument in favor of applicability of the ECHR to non-high contracting parties is as a result of a combined reading of the Article 6 of Lisbon Treaty and the Charter of Fundamental Rights of the European Union. This article has lied down a new foundation of human rights in Europe. For the sake of the clarification, Article reads, "the Union recognizes the rights, freedoms, and principles set out in the Charter of Fundamental Rights of the European Union of 7 December 2000, as adapted at Strasbourg on 12 December 2007, which shall have the same legal value as the Treaties." The Treaty for first time gives legally binding effect to the Charter after a decade (Guild and Monnet, 2013, p. 4). Additionally, one of the main sources of the rights comes from the ECHR (Kühling, 2013) Otherwise sated, so long the provisions of the Charter correspond with the provisions of the ECHR, the scope and interpretation of Charter provisions should be in compliance with ECHR. With the few exceptions such as right to vote accorded by virtue of Article 39 and 40, the Charter's applicability is not limited to citizens of the Union only. To put it differently, the Charter is an enabler for the applicability of ECtHR jurisprudence deriving from the ECHR provision interpretations. So, it is not necessary the accession of EU to the ECHR before taking place the applicability of Charter's provisions (Morano-Foadi \& Andreadakis, 2011, p. 1084). The Charters refers as 'everyone', and it addresses human rights equally to all. In this way, it is shown the Charter's universal applicability.

On that analysis, the cross-referring to Article 41 of the Charter spells out the right to good administration within citizen's rights chapter, and also it stipulates that, "every person has the right to have his or her affairs handed impartially, fairly and within a reasonable time by the institutions and bodies of the Union." Again, the words 'every person' applies equally to everyone without discrimination. For example, in cases of expulsion, the ECtHR assesses, whether the right to enjoy life in conjunction with Article 8 of the ECHR and Article 7 of the Charter, and no difference are made concerning citizenship. Subsequently, the sole concern of the Strasbourg court is whether there is violation of the right under ECHR provisions by way of force removable to another country, and thus jeopardizing the right to private and family life as stipulated in the Convention. In short, the interplay of ECHR and the Charter represents an "assimilation of protection of residence for certain third country nationals to the level enjoyed by Union citizens, diminishes the difference in terms of rights between the third country nationals and EU citizens in a state" (Morano-Foadi \& Andreadakis, 2011, p. 1085).

However, it seems hard to convey direct rights guaranteed by the Charter for those citizens who never happened to be in any of the EU member states. On the other hand, the European Court of Justice (ECJ) can leverage the use of law in a boarder sense, rather in a thin line and so leading to a narrow interpretation of the Charter. In fact, ECJ since 1974 so far has made more than 70 specific references to ECHR by making human rights within the framework of community law (J.Nold, Kohlen- und Baustoffgroßhandlung v. Commission of the European Communities, 1974). In this context Lisbon Treat made EU to some extent subject to the jurisprudence of ECtHR, and so the Charter serves as a vehicle by way of which the integration of EU law is embodied in the jurisprudence of ECtHR, and it leaves no choice but to be honored by EU. In this respect, Article 52 (3) of the Charter calls upon the involved parties to make use of ECHR as minimum standard of protection. The effect of the Charter could be observed from the decision of ECJ in case of Kücükdeveci v. Swedex in 2010 whereby the court utilized the principle of the Article 6 as set out in the Treaty of Lisbon, as a source of human rights rules.

Having established the link between the ECHR and the Charter, it could be further argued that the Lisbon Treaty changed the EU structure of human rights protection in many ways. Furthermore, establishing the linkage of the European Convention of Human Rights with its Court and the EU's Charter will set out a step forward between two institutions, that of EU and the Council of Europe. Undoubtedly a remarkable step constitutes also for non-contracting parties to the ECHR that have set themselves to abide by the Convention's rules and regulations on the applicability span of human rights. 


\section{The Effects of ECtHR Judgments According to the Kosovo Constitutional Court}

The legal relation between the ECtHR and the national courts of member states has attracted the attention of many scholars discussing on this issue. The tens between the two have been visible more often with regard to the effects of the judgments of the ECtHR given by the national court. KCC is not an exception concerning the legal effects of the ECtHR in Kosovo legal order. Indeed, the effects of ECtHR findings reach far beyond the boundaries of Europe, whereby worldwide institutions "will look to Strasbourg jurisprudence for guidance in the adjudication of human rights issues" (Boyle, 2008).

Hence, the ECHR and the judgment of ECtHR have profoundly shape the legal orders of all member states. The influence of the ECtHR judgments has also been extended to non-contracting parties to the convention but has chosen to abide by its provisions. Kosovo is a typical example of the later. On the contrary, even though the decisions of the ECtHR are compulsory upon member states, the Convention provisions do not impose formal obligations upon national courts to give them "direct effect" (CorlaŃean, 2013, p. 1). Be as it may, Article 53 of the Constitution of the Republic of Kosovo paves the way to nurture the effects of ECtHR decided by KCC. So, the merits of the Article 53 set forth that rights and freedoms guaranteed in the Constitution of Kosovo should be interpreted in line with the decisions of the ECtHR. The argument takes its strength by highlighting the worthiness of the Article 112 of para.1, which makes the Constitutional Court ultimate authority for the clarification on Constitution matters.

It goes without saying that KCC is indeed obliged to cultivate affirmative effects to the judgment of the ECtHR. Once again, the effect reflection of the given discussion above is obviously elaborated in the case of Ćemailj Kurtisi where the KCC stated, "the Decisions which emanate from the courts that adjudicate on these Conventions, principally the European Court of Human Rights sitting in Strasburg, aid and assist not only all the Courts of Kosovo but other State organs as to how fundamental rights and freedoms must be interpreted and applied in Kosovo." (Case No. KO 01/09, para 34). Even though to a great extend the applicability of jurisprudence of ECtHR is quite clear, nonetheless, it is not quite clear as to what extent the scope of interpretive powers of KCC may go. Meaning to say, whether KCC is obliged $100 \%$ to follow the jurisprudence of ECtHR or perhaps there is some limitation to that. For instance, what relevance has the margin of appreciation concept in Kosovo's context and how this concept should be leveraged based on circumstances in Kosovo?

In any event, the reliance of national courts, especially KCC have time-to-time referred or draw from the ECtHR's judgments of human rights. An illustrative example for making up this point is the case of Imer Ibrahimi and 48 other former employees of Kosovo Energy Corporation (2010) known as KEK cases. In deciding on issues of right to property and fair trial rights, the KCC retreats on the jurisprudence of the European Court of Human Rights, and thus directly translating the effects of ECtHR's judgments into the legal Kosovo system.

The contemporary European system of human rights expressed in ECHR is clearly and precisely inculcated within all domestic legal systems of the European continent, thus outlining sound principles of human rights. Kosovo also takes an unequivocal position by instilling the provisions of ECHR and the principles of ECtHR by virtue of Article 22. It appears to one's mind or opinion that the existing Article 53 has a certain outward aspect with regard to the relevance of the ECHR and its Court into Kosovo's legal system.

The aftermath of Article 53 in relation to Kosovo's Constitutional Court is clear in setting out a mandatory reference to the ECtHR case law. The central meaning of it is that the jurisprudence of ECtHR is binding authority for constitutional interpretations by all institutions operating within Kosovo's legal order. Additionally, Article 53 legitimizes the authority of the Constitutional Court to cite Strasbourg cases for an effective protection of human rights in questions posed from the authorized parties determined by the Constitution of Kosovo. The practice of applying ECtHR principles by KCC compliments ECtHR practices within our system and this is evident in dozens of KCC judgments.

Another beneficial effect of reference by KCC to ECtHR case law is that by so doing, the Constitution of Kosovo could well enhance its practical jurisprudence by gaining from a wide scope of the state practices within the Council of Europe. It could take advantage from the settled standards of judicial review applied by the ECtHR with regard to ECHR. In turn, this would help harmonization of the Constitution of the Republic of Kosovo "with the recent European human rights law developments and contributes to the further Europeanization of Kosovo constitutional law"(Botusharova, 2010, p. 79). Undeniably, this view would ease Kosovo's road map to deepen its integration processes in the European Union.

Moreover, a combined interaction of articles 22 and 53 of the Constitutions of the Republic of Kosovo on the basis of normativity bestows an enhanced approach for KCC that in turn goes far beyond the protection regime laid down in the ECHR. This argument is said to transpose the words of ECHR and it's Court's findings as an avenue to fill up the disparity for protection of human rights, knowing the fact, that as of yet Kosovo is not a member of the Council of Europe. Thus, by assigning higher status to ECHR than the laws of Kosovo secures constitutional status to the principles of ECtHR case law. Indeed, the Strasbourg case law is constitutionalized by virtue of Article 53, which has direct implication 
in Kosovo as a source of law (Pavlin, 2010, p. 95). Thus, it is not surprisingly to see the role of Constitutional Court as a guardian whose responsibility is to bridge any disparity between the Constitution Court of the Republic of Kosovo and the European Convention. Nevertheless, in theory, by no means the authors of this paper are claiming that citizens of Kosovo have no right to claim their rights in Strasbourg. But the problem is whether they may do so in practice and this is where Kosovo's citizens are missing the opportunity to do so. This point will be elaborated in greater detail in the following section by referring to the Saramati and Behrami case.

\section{Challenges Facing ECtHR and the Constitutional Court of Kosovo}

So far, it is understood that the functionality of Strasbourg system is based on ECHR provisions, interpreted by the ECtHR while responsible authority concerning with administrative work is carried out by the Council of Europe. Indicatively, the ECtHR have made known that it does not furnish different treatment to people coming for different countries (Morano-Foadi \& Andreadakis, 2011, p. 1087) on the basis of nationalities as is not decisive criteria of admissibility for the Court. Nevertheless, admissibility criteria are among the most challenging factor for both Courts. Not everybody may bring a case before the two according to his whim and wishes unless admissibility criteria are fulfilled. For instance both courts share same similarity when it comes to the criteria of exhausting all remedies. In contrary, nationality plays role for purpose of claiming rights at ECtHR bur it is not the case with KCC within its jurisdiction. Based on the statistics almost $90 \%$ of referrals to both Courts are dismissed due to the lack of admissibility criteria. In any event, ECtHR remain the most suitable vehicle to carry out remedies for the affected victims.

In one hand, ECtHR is perceived as the most effective institution adjudicating on defense of human rights. On the other hand, ECtHR is facing tremendously the increase of its caseload and this is undoubtedly one of the greatest challenges faced by the ECtHR. So the other side of the coin risks weakening the achievements by the so-called 'looming crises facing the Court'. As of January $31^{\text {st }} 2013$, a total number of pending applications amounts to 126,850 (ECtHR, 2013).

An additional challenge faced by the ECtHR is violation of judgments by states. Here more than half of the judgments delivered by the Court belong to the four states of the Council of Europe: "Turkey (2,295 judgments), Italy (2,021 judgments), Russia (862 judgments) and France (773 judgments). Of the total number of judgments it has delivered since it was established in 1959, over $83 \%$ of cases the Court has found at least one violation of the Convention by the respondent State (ECtHR, 2013). Nevertheless, the Court is not totally indifferent as it has taken concrete steps by reforming ECtHR in a attempt to address at least the first challenged posed above. The enforcement of KCC judgments in several cases proved to be quiet challenging.

Other than that, the individual right to bring his/her claim before the ECtHR and before the Constitutional Court of Kosovo appears to be the next challenge faced at the forums of both courts. In fact, the challenge is not about an individual right to lodge a claim, rather the challenge comes from a sharp criticism predominately from lawyers and nongovernmental organizations because $90 \%$ of the referrals will be declared as inadmissible without giving detailed reasons. Of similar critical appraisal was the issue with Behrami and Saramati case, but before fleshing out few more facts regarding these cases, it is worthwhile pointing out that admissibility criteria of ECHR is reflected in the Constitution of Kosovo and therefore has equal impacts on admissibility decisions. Respectively the interaction of KCC and ECtHR is not only matched in deciding substantive rights, but also with regard to procedural rights and the admissibility of individual referrals as stipulated in Article 113 para 7 (Article 34 ECHR) of the Constitution. Of course, all necessary requirements have to be fulfilled before the application will become admissible. Significant challenge remains as to who has right to claim his/her right to ECtHR and /or KCC?

Turning to the Behrami and Saramati cases, it was exactly on the lacking grounds of admissibility criteria that the case was declared inadmissible. In fact, the court addressed the issue from the standpoint of attribution. The main issue was that of interpretation of the jurisdiction and the effect of the extraterritoriality application of the ECHR as decided by the ECtHR in familiar cases, such as Loizidou v. Turkey, Bankovic and Others v. Belgium and Others, \& Ilascu and others v. Moldova and Russia. The ECtHR, however, approached different way of addressing these cases: Accordingly they stated:

"[T]he question raised by the present cases is, less whether the respondent States exercised extra-territorial jurisdiction in Kosovo but far more centrally, whether this Court is competent to examine under the Convention those States' contribution to the civil and security presences which did exercise the relevant control of Kosovo.

Accordingly, the first issue to be examined by this Court is the compatibility ratione personae of the applicants' 
complaints with the provisions of the Convention" (Behrami and Behrami v. France, Saramati v. France, Germany and Norway, 2007).

The case of Behrami and Saramit is a court demonstration as to how the court will restore to framing the question as a way of avoiding to answering on the issues stressed out above.

\section{Conclusion}

Fundamental rights and freedoms, protected by legal norms, are defined by clear parameters, in numerous internal and international legal documents. Setting from this point, twinning of national and international law inevitably emphasizes the connection and the dominating influence of the ECHR on national systems embracing the monist system, with a special emphasis on the case of Kosovo.

The observation of provisions of the ECHR and its protocols is enshrined in Article 22 of the Constitution of Kosovo safeguarding human rights in Kosovo's constitutional system. The paper highlights the challenges and achievements of Kosovo's constitutional jurisprudence in defending fundamental human rights and freedoms. Consequently, the clear and simple conclusion is that in practice, ECHR enjoys high reliability by KCC. Constitutional jurisprudence and decisions are consolidated through monist approach, thereby properly accommodating the Strasbourg case law.

Furthermore, the Constitutional Court of Kosovo' role as a Constitution defender and guarantor amount to a "linking bridge" between the Constitution of the Republic of Kosovo and the European Convention on Human Rights. Nevertheless, in practice Kosovo citizens cannot demand protection of their rights in Strasbourg since Kosovo is not a contracting party to the Convention. The argument that protection of rights and freedoms should not be considered from the viewpoint of whether it is or not a member of the Council of Europe, represents the strongest and the most convincing thought that decisions of the KCC related to individual referrals should be able to be subject to European Court review. These decisions would be subject to an ultimate control or filtration by a specialized court and extensively experienced judges in reviewing and adjudicating human rights and freedom cases. Indeed, perhaps this is the greatest advantage to justify Kosovo's access to the ECHR.

The assigning of higher status of ECHR over the laws of Kosovo secures constitutional status for the principles of ECtHR case law.

Taking into account that Kosovo is relatively a new country and yet has long way to the perfection of its legal system, the direct application of ECHR and ECtHR serves as an avenue to fill up the discrepancy for protection of human rights. It could take advantage from the settled standards of judicial review applied by the ECtHR with regard to ECHR.

\section{References}

Bente, C. (2011). The OSCE and the Problem of Human Rights. Society and Politics, Vol.5, No. 1(9).

Boyle, K. (2010). The European Experience: The European Convention on Human Rights. Victoria U Wellington L Rev, 40, 168.

Corlăţean, P. D. T. (2011). Considerations regarding the authority of the european convention on human rights and fundamental freedoms and of the european court on human rights jurisprudence on the national law systems in some of the member states. Law Review: Judicial Doctrine \& Case-Law. Retrieved from http://www.internationallawreview.eu/fisiere/pdf/03-Titus-Corlatean. pdf.

Guild, E., \& Monnet, Jean. (2013). What Fundamental Rights for whose EU Citizens?, 4. Retrieved from http://ec.europa.eu/education/ jean-monnet/doc/ecsa10/guild_en.pdf.

Hasani, E. Paczolay, P. \& Riegner, M. (Eds). (2012). Constitutional Justice in Southeast Europe, Constitutional Courts in Kosovo, Serbia, Albania, and Hungary between Ordinary Judiciaries and the European Court of Human Rights, Prishtine.

Istrefi, K. et al. (2013). Constitutional Domestication of International Human Rights. In Q. Qerimi (eds in chief). Journal for Juridical and Social Issues, Law Nr 1/2013, pp 267-282.

Kühling, J. (2010). Fundamental Rights. In von Bogdandy, A \& J Bast Principles of European Constitutional Law Hart, Oxford.

Michael Boyle, M. (2008). On Reforming the Operation of the European Court of Human Rights, EHRLR 1.

Morano-Foadi, S., \& Andreadakis, S. (2011). The Convergence of the European Legal System in the Treatment of Third Country Nationals in Europe: The ECJ and ECtHR Jurisprudence. European Journal of International Law, 22(4), 1071-1088.

Morina, V., Korenica, F., \& Doli, D. (2011). The relationship between international law and national law in the case of Kosovo: A constitutional perspective. International journal of constitutional law, 9(1), 274-296.

Muharremi, R. (2010). The European Union Rule of Law Mission in Kosovo (EULEX) from the perspective of Kosovo constitutional law. Zeitschrift für ausländisches öffentliches Recht und Völkerrecht, 70, 357-379.

Arben Krasniqi et al., Ruling on admissibility of Agim Zogaj's statements and diaries (also known as witness X), District Court of Pristina, Case P No. 425/11, 21 March 2012.

Bankovic and Others v. Belgium and Others, App. No. 52207/99, Grand Chamber, Decision on admissibility, 12 December 2001, 
hereinafter Bankovic.

Behrami and Behrami v. France, Saramati v. France, Germany and Norway, App. Nos. 71412/01 \& 78166/01, Grand Chamber, Decision, 2 May 2007, paras 71-72.

Case No. KI 40/09, judgment of 23rd June 2010, paras 51-55, 68.

Case No. KI 40/09, judgment of 23rd June 2010. Retrieved from http://www.gjkks.org/repository/docs/ki_40_09_ang_vendimi_meritor.pdf, accessed on March 28, 2014.

Case No. KO 01/09, judgment of 18 March , 2010, para 34. Retrieved from http://www.gjk-ks.org/repository/docs/ko_01_09_Ven_ ang.pdf., accessed on March 27, 2017.

Ćemailj Kurtisi, v. The Municipal Assembly of Prizren, Case No. KO 01/09, judgment of 18 March , 2010, paras 34, 40. Retrieved form http://www.gjk-ks.org/repository/docs/ko_01_09_Ven_ang.pdf., accessed on March 27, 2014.

Constitution of the Republic of Kosovo, Jun $200 \overline{8}$.

Illascu and others v. Moldova and Russia, App. No. 48787/99, Grand Chamber, Judgment, 8 July 2004.

J.Nold, Kohlen- und Baustoffgroßhandlung v. Commission of the European Communities [1974] Case 4/73, ECR. 491.

Kücükdeveci v Swedex, Judgment of the Court (Grand Chamber) of 19 January 2010', 11 German LJ (2010) 539.

Loizidou v. Turkey, App. no. 15318/89, Judgment (preliminary objections), 23 February 1995; Judgment (merits), 28 November 1996.

Assembly of Kosovo. (2008). Kosovo Declaration of Independence. Retrieved from http://www.assembly-kosova.org/?cid=2,128,1635.

European Convention on Human Rights. (2013). Retrieved from http://www.echr.coe.int/NR/rdonlyres/D5CC24A7-DC13-4318-B4575C9014916D7A/0/Convention_ENG.pdf.

European Court of Human Rights. (2013). Retrieved from http://www.echr.coe.int/NR/rdonlyres/ACD46A0F-615A-48B9-89D6-8480AF CC29FD/0/FactsAndFigures_EN.pdf.

Foreign and Commonwealth Office London. (2007). Consolidated Texts of the Eu Treaties as Amended by the Treaty of Lisbon. Retrieved from http://www.official-documents.gov.uk/document/cm73/7310/7310.pdf Article 6 (1).

OSCE. (2013). Retrieved from http://www.osce.org/who/83.

United Nations (2007). Comprehensive Proposal for the Kosovo Status Settlement, docs, S/2007/168/Add.1. Retreved from http://www.unosek.org/docref/Comprehensive_proposal-english.pdf. 